\title{
Incidental Gallbladder Cancer after Laparoscopic Cholecystectomy for Cholelithiasis, and Factors Affecting the Prognosis: A Single-center Experience
}

\section{Kolelitiyazis için Uygulanan Laparoskopik Kolesistektomi Sonrası Rastlantısal Safra Kesesi Kanseri ve Prognozu Etkileyen Faktörler: Tek Merkez Deneyimi}

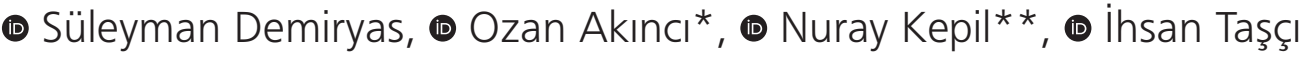 \\ istanbul University-Cerrahpaşa, Cerrahpaşa Faculty of Medicine, Department of General Surgery, Istanbul, Turkey \\ *Hakkari State Hospital, Clinic of General Surgery, Hakkari, Turkey \\ **istanbul University-Cerrahpaşa, Cerrahpaşa Faculty of Medicine, Department of Pathology, Istanbul, Turkey
}

\section{Abstract}

\begin{abstract}
Aim: Despite surgical and radiological innovations, gallbladder cancer (GC) is usually diagnosed incidentally by the pathological examination of the cholecystectomy specimens, and it is defined as incidental GC (IGC).
\end{abstract}

Methods: Medical files of patients, who underwent cholecystectomy, were analyzed retrospectively. We investigated the relationship between clinicopathological features and survival in patients with IGC.

Results: We performed cholecystectomy surgery in 6225 patients in 20 years. Only 21 patients with IGC were included in this study. The distribution of the tumor stages was as follows: in situ cancer $(n=1), T 1(n=2), T 2(n=7)$, and T3 $(n=11)$. Tumor subtypes were identified as adenocarcinoma $(n=16)$, neuroendocrine tumor $(n=2)$, mucinous carcinoma $(n=2)$, and adenosquamous carcinoma ( $n=1)$. Advanced "T stage", conversion of laparoscopic cholecystectomy to open cholecystectomy (OCC), positive surgical margins, positive lymphovascular invasion and increased levels of pre-operative alkaline phosphatase (ALP) were found to be associated with poor survival.

Conclusion: In case of OCC or high preoperative ALP activity in cholelithiasis, IGC should be kept in mind. Pathology report on IGC should give information on all histopathological prognostic features in order to avoid loss of time associated with re-examination of specimens due to absence of sufficient information in the initial pathology report and enable the surgical team to perform re-operation for T1b tumors or more advanced IGC in a timely fashion.

Keywords: Cholelithiasis, incidental gallbladder carcinoma, neuroendocrine carcinoma, lymphovascular invasion, laparoscopic cholecystectomy, alkaline phosphatase
Öz

Amaç: Cerrahi ve radyolojik yeniliklere rağmen, safra kesesi kanseri (GC) kolesistektomi sonrası patolojik incelemede genellikle rastlantısal olarak teşhis edilir ve rastlantısal GC (IGC) olarak tanımlanır.

Yöntemler: Kolesistektomi yapılan hastaların tıbbi dosyaları retrospektif olarak incelendi. IGC'de klinikopatolojik özellikler ile sağkalım arasındaki ilişkiyi araştırdık.

Bulgular: Yirmi yılda 6225 hastaya kolesistektomi uyguladık. Bu çalışmaya sadece 21 IGC hastası dahil edildi. Tümör evrelerinin dağılımı: in situ kanser $(n=1), T 1 \quad(n=2), T 2(n=7)$ ve T3 ( $n=11)$ olarak bulundu. Tümör alt tipleri, adenokarsinom $(n=16)$, nöroendokrin tümör $(n=2)$, müsinöz karsinom $(n=2)$, adenoskuamöz karsinom ( $n=1)$ olarak tanımlandı. ileri evre $T$ evresi, laparoskopik kolesistektomide açık kolesistektomi dönüş (OCC), pozitif cerrahi sınır, pozitif lenfovasküler invazyon ve preoperatif alkalen fosfatazın (ALP) yüksek aktivitesinin sağkalım süresini kısalttığı saptadık.

Sonuç: Kolelitiaziste OCC veya preoperatif ALP'nin yüksek aktivitesi durumunda, IGC'yi aklımızda tutmalıyız. Patologlar, IGC'yi teşhis ettiklerinde tüm histopatolojik prognostik faktörleri içeren bir rapor sunmalıdırlar. Böylece revizyon patolojisi için zaman kaybedilmeyecek, T1b veya daha ileri T-evreleri için reoperasyon uygun zamanda uygulanabilecektir.

Anahtar Sözcükler: Kolelitiyazis, rastlantısal safra kesesi karsinomu, nöroendokrin karsinom, lenfovasküler invazyon, laparoskopik kolesistektomi, alkalen fosfataz
Address for Correspondence/Yazışma Adresi: Süleyman Demiryas, İstanbul UniversityCerrahpaşa, Cerrahpaşa Faculty of Medicine, Department of General Surgery, İstanbul, Turkey E-mail: suleyman.demiryas@istanbul.edu.tr ORCID: orcid.org/0000-0002-0050-9099 Received/Geliş Tarihi: 25 April 2019 Accepted/Kabul Tarihi: 25 April 2019
${ }^{0}$ Copyright 2019 by The Medical Bulletin of istanbul Haseki Training and Research Hospital The Medical Bulletin of Haseki published by Galenos Yayınevi. ${ }^{\circledR}$ Telif Hakkı 2019 Istanbul Haseki Eğitim ve Araştırma Hastanesi Haseki Tıp Bülteni, Galenos Yayınevi tarafından yayınlanmıştır. 


\section{Introduction}

Gallbladder carcinoma (GC) is the fifth most common cancer of the gastrointestinal tract (1-5) and the most common malignancy of the biliary tract $(3,5)$. The overall incidence of GC is $2.5-3$ per 100,000 people $(3,4,6)$. The most important curative treatment for $G C$ is surgical resection; the curative efficacy of both radiation therapy and systemic chemotherapy are still uncertain $(6,7)$. The 5 -year survival rate for all stages of GCs is $2.7-15 \%$ (1$4,8,9)$.

Gallbladder cancer, incidentally diagnosed during pathological examination of the gallbladder specimen after cholecystectomy performed for other indications, is defined as incidental GC (IGC) $(1,8,10-12)$. It was first defined by Marcial-Rojas (13) in 1961. 27-41\% of the GC cases are diagnosed primarily as IGC, however, this rate, ranges from $10 \%$ to $93 \%$ depending on the different series reported $(7,8,14)$. While physicians suspect GC preoperatively in $30 \%$ of all cases, it is diagnosed in pathological examination of cholecystectomy specimens in the majority of cases $(4,6)$.

The presence of gallstones, calcification, inflammation, anomalous pancreatobiliary junction, and polyps are the known risk factors for the development of GC. In addition, advanced age, female gender, obesity, ethnicity (such as Hispanic race) and various geographical regions (such as Chile, Northern India) are also related with higher incidence of $\mathrm{GC}(3,8,14,15)$. Goetze (8) defined gallstones and chronic cholecystitis, as the most important risk factors for the development of the GC. Moreover, it was proposed that any increase in the size of gallstones would be associated with high risk of developing GC. The incidence of GC presenting with acute cholecystitis (AC) is higher than that of diagnosed during elective cholecystectomy for cholelithiasis (16). A recent study performed by Kim et al. (16) concluded that both GC and AC cause thickening of the gallbladder wall rendering the differential diagnosis of these two diseases complicated. Gallstones are found in $70-98 \%$ of patients with $\mathrm{GC}(5,9)$. The most important risk factor for GC has been reported to be cholelithiasis (17). The incidence of GC related to cholelithiasis varies from $0.3 \%$ to $12 \%(6)$. The preoperative diagnosis of GC in these patients could be difficult due to the fact that the clinical and radiological presentation may be masked by acute or chronic cholecystitis $(12,14,18)$. Laparoscopic cholecystectomy (LC) has received broad acceptance. In the Western countries, LC constitutes almost $90 \%$ of all cholecystectomies $(8,14,19)$. With the widespread use of LC, the diagnosis of IGC at early stages has become easier $(6,17)$. However, the widespread use of $L C$ has not changed the prevalence of GC considerably (14).
Treatment of IGC includes surgical methods varying from simple cholecystectomy to radical cholecystectomy $(1,2)$. The objective of re-exploration and definitive resection is to eliminate likely areas locoregional residual disease (11). Radical resections may improve survival in patients with $\mathrm{T} 4$ stage tumors without remote metastases or dissemination (20). Tumor stage is the strongest predictor of overall survival (21).

We investigated the relationship between clinicopathological features and survival in patients with IGC. Our objective was also to determine prognostic factors in patients who received the diagnosis of IGC after cholecystectomy.

\section{Methods}

This retrospective study was carried out in accordance with the principles of the Declaration of Helsinki and after obtaining approval of the Istanbul UniversityCerrahpaşa, Cerrahpaşa Faculty of Medicine Faculty of Medicine-Institutional Review Board (Number: 83045809/604.01/02-82599). Medical records of 6225 patients, who underwent cholecystectomy for benign gallbladder pathologies between January 1998 and January 2018, were screened. Patients with suspected malignant diseases, AC and acalculous cholecystitis, those who underwent open cholecystectomy (OC), frozen procedure, re-operation and LC for polyp, and those who were lost to follow-up were excluded from the study. Only 21 IGC patients were included in our study (Figure 1).

We routinely perform LC using the four-trocar technique. We use a retrieval bag for LC during extraction. We place a drain in the subhepatic space in patients with high risk of bleeding.

Personal address and contact details of the patients who underwent LC were obtained from the institutional records. Patients or their relatives were contacted via telephone calls to determine their survival status. The health status of the patients who survived during the interview, date of death and the causes of death were investigated. One patient who could not be contacted directly and/or through her care giver was excluded from the study. Survival time was determined from the date of diagnosis to the date of death or to the date of last followup.

All cases were re-evaluated according to the tumor, nodes, metastases (TNM) system designed by the American Joint Committee on Cancer (AJCC) for staging GC. The TNM system classifies cancers by the size and extent of the primary tumor $(T)$, involvement of regional lymph node $(L N)$, and the presence or absence of distant metastases (M), supplemented in recent years by carefully selected non-anatomic prognostic factors. For this 
purpose, the " 7 th edition of the AJCC staging" system was used (22).

The demographic data, operative data and preoperative clinical laboratory results, such as serum albumin, lactate dehydrogenase (LDH), alkaline phosphatase (ALP) and blood hemoglobin $(\mathrm{Hb})$, preoperative radiological examination reports and their related pathology results were also evaluated. Serum LDH, ALP and albumin levels were assayed in Roche $\mathrm{c} 8000^{\circledR}$ auto analyzer. $\mathrm{Hb}$ concentrations were estimated in the Beckman LH 780 ${ }^{\circledR}$ autoanalyzer using the cyanmethemoglobin method. Values of $L D H \geq 250 \mathrm{IU} / \mathrm{L}$, albumin $<530 \mu \mathrm{mol} / \mathrm{L}, \mathrm{ALP} \geq 105$ $\mathrm{IU} / \mathrm{L}$, and $\mathrm{Hb} \leq 120 \mathrm{~g} / \mathrm{L}$ were all considered diagnostic cut off points.

\section{Statistical Analysis}

We performed statistical analyses using the SPSS software version 20 (IBM Analytics, Armonk, New York, USA). The categorical variables were expressed as frequencies (\%), and the continuous variables were investigated using visual (histograms, probability plots) and analytical methods (Kolmogorov-Simirnov/Shapiro-
Wilk test) to determine whether they were normally distributed. If values were normally distributed, we used mean and standard deviation to express data. If not, we used median to express our data. Clinical chemistry parameters were compared between dichotomous categorical variables using the Mann-Whitney $U$ test. Survival outcomes were compared using the Kaplan-Meier method with the log-rank test, and potent survival factors were verified using the Cox regression model. A p value of less than 0.05 was considered statistically significant.

\section{Results}

Of the 6225 patients, 749 (12\%) underwent OC. LC $(88 \%)$ was done in 5476 patients; in $183(3 \%)$ of whom the technique was converted to OC (OCC). IGC was diagnosed in $43(0.78 \%)$ of these patients. The incidence of IGC was found to be $5.5 \%$ in our patients with OCC. Of patients who underwent LC, 3723 (68\%) were women and $1753(32 \%)$ men.

Only 21 IGC patients (15 female, six male) with the mean age of $69.67 \pm 12.86$ years were included in the study (Figure 1). The median survival was $7.00 \pm 3.81$ months. The

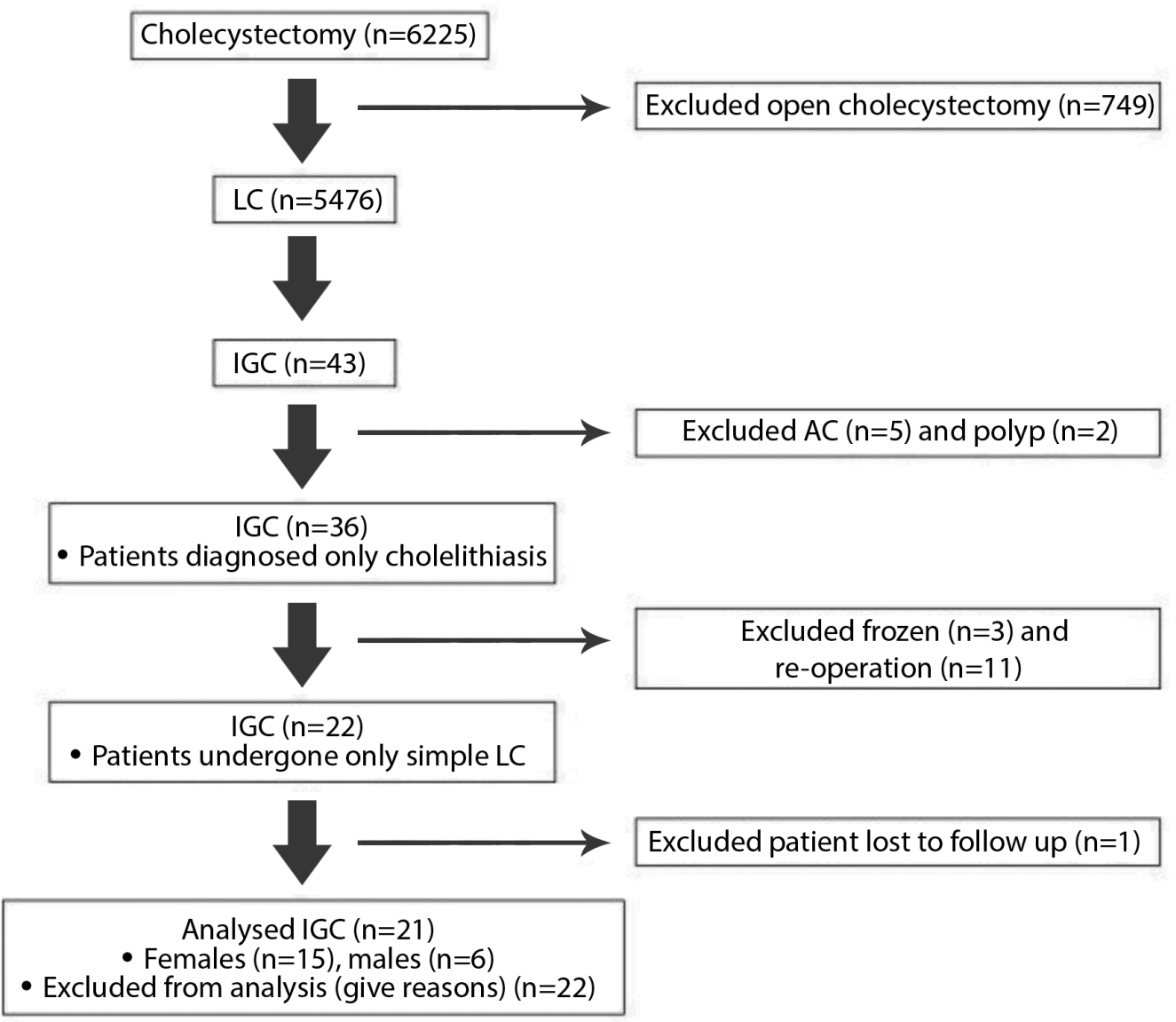

Figure 1. Flowchart for patient selection (LC: laparoscopic cholecystectomy; IGC: incidental gallbladder carcinoma; AC: acute cholecystitis) 
median survival was $6.00 \pm 2.15$ months in female patients. Sixteen were geriatric patients. The median survival in the non-geriatric population was $9.00 \pm 5.48$ months, whereas, it was $6.00 \pm 3.00$ months in the geriatric population. We have not found any effect of gender, age and being in the geriatric population on survival in our study.

In 11 of the patients, LC was successfully completed, however, an OCC was deemed necessary in 10 of the patients. Survival was significantly longer in patients whose LC procedures were completed successfully $(p=0.009)$ (Figure 2). The median survival was $60.00 \pm 37.89$ months after LC and 2.00 \pm 0.95 months after OCC.

Survival analyses for the location of IGC at the fundus, body, and neck regions of the gallbladder could not be performed. IGC was detected in the fundus, body and the neck regions in 3, 16, and two of patients, respectively. IGC involved the peritoneal surface $(n=14)$ or the hepatic bed $(n=7)$. Involvement of the hepatic bed or the peritoneal surface seems not to be a statistically significant factor determining survival. However, survival was found to be longer in patients with IGC involving the peritoneal surface (Table 2).

Gallbladder perforation (GP) occurred in 6 patients during surgery. The median survival was found to be 2.00 \pm 3.67 months in patients with $\mathrm{GP}$, and it was

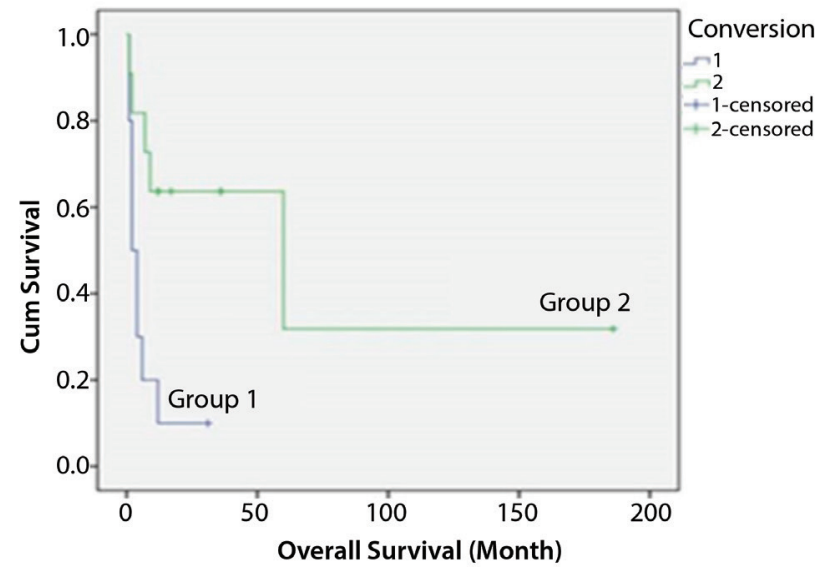

Figure 2. Kaplan-Meier survival curves according to conversion from laparoscopic cholecystectomy (Group 2) to open cholecystectomy (Group 1)
9.00 \pm 5.15 months in patients without GP $(p=0.548)$. Although it seems not statistically significant, it was noteworthy that survival was shorter in patients with IGC complicated with the occurrence of GP.

Histopathological type and $T$ stage distributions of the cases are given in Table 1. One patient with Tis and 2 with T1b were excluded from the survival analysis due to the small sample size. The median survival was longer in patients with T2 IGC than in those with T3 IGC (Figure 3). The patient with Tis was in the postoperative (PO) 186th month and those with $\mathrm{T} 1 \mathrm{~b}$ were in the PO $12^{\text {th }}$ and $36^{\text {th }}$ months. In patients with only adenocarcinoma, there was no significant difference in survival between T2 and T3 stages ( $p=0.091)$. One of the two patients with mucinous adenocarcinoma was found to be still alive in the $31^{\text {st }}$ PO month in the T2 stage, however, the other one died in the PO first month in the stage T3. The patient with adenocarcinoma had T3 tumor and died 6 months after the definitive operation. The patients with neuroendocrine carcinoma had stage T3 disease and lost their lives within the PO first and fourth months.

According to histologic grading, 11 patients had welldifferentiated ICG, four had moderately differentiated, and 6 patients had poorly differentiated ICG. Although we found no statistically significant effects of the grades

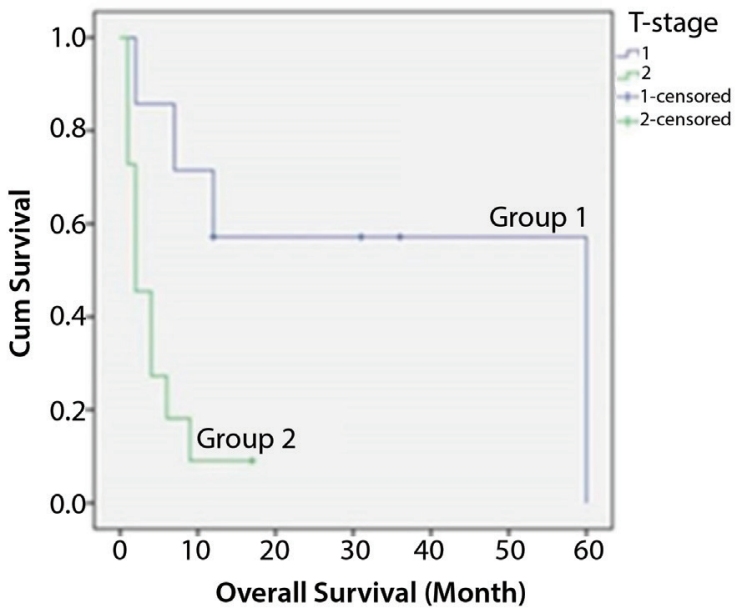

Figure 3. Kaplan-Meier survival curves according to T-stages (Group 1, T2 patients; Group 2, T3 patients)

Table 1. T stages and histopathological types in incidental gallbladder cancer

\begin{tabular}{|l|l|l|l|l|l|}
\hline & Adenocarcinoma $(\mathbf{n}=\mathbf{1 6})$ & $\begin{array}{l}\text { Mucinous adenocarcinoma } \\
(\mathbf{n}=\mathbf{2})\end{array}$ & $\begin{array}{l}\text { Adenosquamous carcinoma } \\
(\mathbf{n}=\mathbf{1})\end{array}$ & $\begin{array}{l}\text { Neuroendocrine carcinoma } \\
(\mathbf{n}=2)\end{array}$ & $\begin{array}{l}\text { Total } \\
(\mathbf{n}=\mathbf{2 1})\end{array}$ \\
\hline Tis & 1 & - & - & - & 1 \\
\hline T1b & 2 & - & - & - & 2 \\
\hline T2 & 6 & 1 & - & - & 7 \\
\hline T3 & 7 & 1 & 1 & 2 & 11 \\
\hline
\end{tabular}


on survival, it was noteworthy that survival was longer in patients with well-differentiated tumors (Table 2).

The median of tumor diameter (TD) was $35000 \mu$. Of the IGC patients, nine of them have had tumors measuring $35000 \mu$ in diameter or larger. Although the difference was not statistically significant (Table 2), patients with tumors $<35000 \mu$ had longer survival.

In 12 of the cases, regional LN could not be evaluated. Four of the cases had positive LN metastasis but five were $L N$-negative. The effect of regional LN involvement on survival could not be assessed. Perineural invasion (PI) was found in 11 patients. No significant difference was found in survival between patients with and without PI (Table 2).

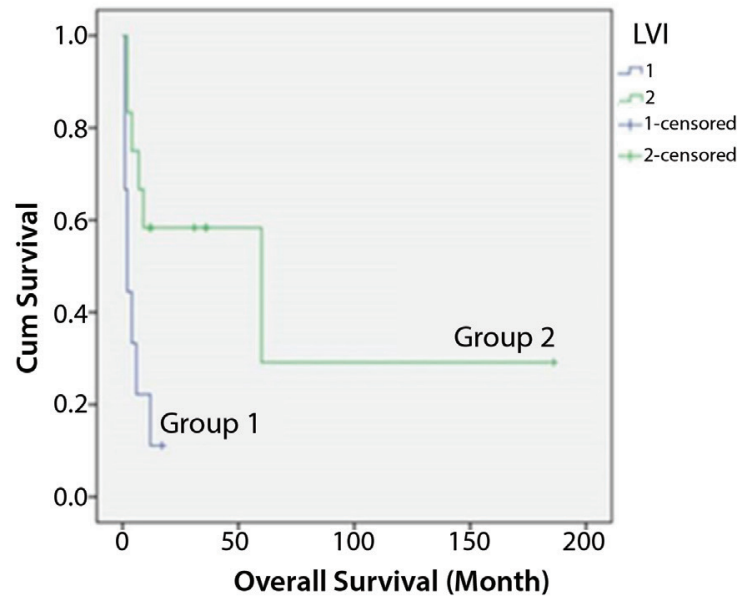

Figure 4. Kaplan-Meier survival curves according to lymphovascular invasion. (Group 1 positive LVI, Group 2 negative LVI) LVI: Lymphovascular invasion
Nevertheless, it seems that patients without PI had longer survival. Lymphovascular invasion (LVI) was identified in 12 patients. The median survival in patients with LVI was $2.00 \pm 0.75$ months, shorter than that in patients without LVI (Table 2 and Figure 4). Surgical margins (SM) were positive in nine of the patients. SM-positive patients had shorter survival durations (Table 2 and Figure 5).

The mean activity of LDH was $341 \pm 142.45 \mathrm{IU} / \mathrm{L}$, and the median survival was found to be $4.00 \pm 3.00$ months for patients with high LDH levels $(p=0.242)$. The mean serum albumin concentration was $600 \pm 85 \mu \mathrm{mol} / \mathrm{L}$ and the median survival was found to be $9.00 \pm 5.00$ months in patients with low albumin levels $(p=0.125)$. The mean

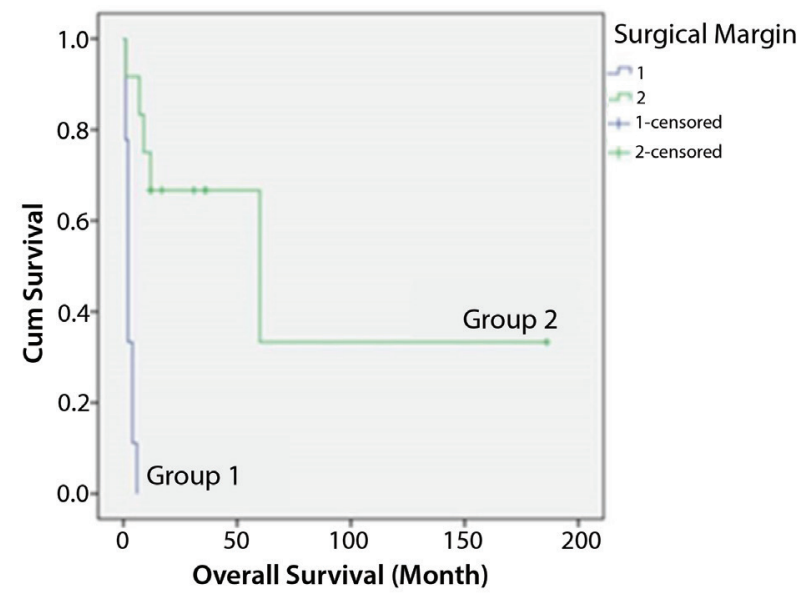

Figure 5. Kaplan-Meier survival curves according to the surgical margins (SM). (Group 1 positive SM, Group 2 negative SM)

\begin{tabular}{|c|c|c|c|c|}
\hline & & Number of patients $(n)$ & Median survival (Months) & $p$ \\
\hline \multicolumn{2}{|l|}{ The median survival of patients } & 21 & $7.00 \pm 3.81$ & \\
\hline \multirow{2}{*}{ T staging } & $\mathrm{T} 2$ & 7 & $60.00 \pm 0.00$ & \multirow{2}{*}{0.011} \\
\hline & T3 & 11 & $2.00 \pm 0.99$ & \\
\hline \multirow{3}{*}{ Histologic grading } & Well differentiation & 11 & $60.00 \pm 41.60$ & \multirow{3}{*}{0.092} \\
\hline & Moderate differentiation & 4 & $6.00 \pm 2.50$ & \\
\hline & Poor differentiation & 6 & $2.00 \pm 1.84$ & \\
\hline \multirow{2}{*}{ Tumor location } & Peritoneal surface & 14 & $9.00 \pm 22.03$ & \multirow{2}{*}{0.173} \\
\hline & Hepatic bed & 7 & $4.00 \pm 1.19$ & \\
\hline \multirow{2}{*}{ Tumor diameter } & $<35 \mathrm{~mm}$ & 12 & $60.00 \pm 39.65$ & \multirow{2}{*}{0.053} \\
\hline & $\geq 35 \mathrm{~mm}$ & 9 & $4.00 \pm 1.49$ & \\
\hline \multirow{2}{*}{ Perineural invasion } & Positive & 11 & $4.00 \pm 2.20$ & \multirow{2}{*}{0.087} \\
\hline & Negative & 10 & $60.00 \pm 39.90$ & \\
\hline \multirow{2}{*}{ Lymphovascular invasion } & Positive & 12 & $2.00 \pm 0.75$ & \multirow{2}{*}{0.011} \\
\hline & Negative & 9 & $60.00 \pm 38.15$ & \\
\hline \multirow{2}{*}{ Surgical margin } & Positive & 9 & $2.00 \pm 0.35$ & \multirow{2}{*}{0.016} \\
\hline & Negative & 12 & $60.00 \pm 35.32$ & \\
\hline
\end{tabular}


level of $\mathrm{Hb}$ was $124.9 \pm 12.2 \mathrm{~g} / \mathrm{L}$. No effects of low levels of $\mathrm{Hb}$ on survival was identified $(p=0.276)$. The mean ALP activity was $176.57 \pm 119.83 \mathrm{IU} / \mathrm{L}$. The median survival was found to be $4.00 \pm 0.95$ months for patients with high ALP levels. High levels of ALP were found to be significantly related to shorter survival $(p=0.009)$ (Figure 6).

\section{Discussion}

Despite considerable improvement achieved in the early diagnosis of $\mathrm{GC}$ with the use of radiologic advancements, the incidence of IGC is still 0.2-3\% worldwide $(2,12,16)$. LC as a surgical treatment for cholelithiasis has replaced OC lately $(12,16,18,23,24)$. It is estimated that the incidence of IGC after LC varies from 0.09 to $2 \%(3,16,25)$. The incidence of IGC in our 20-year of cholecystectomy series was $0.78 \%$.

In many studies, female gender or age 65 years or older has been considered risk factors for IGC $(2,3,14,17)$. In our cases, fifteen patients were female and their median age was $69.67 \pm 12.86$ years. We did not find a statistically significant effect of gender or advanced age on survival.

Ahn et al. (2) emphasized that operative procedures should be considered independent prognostic factors. In our cases, OCC was done in 10 patients. IGC incidence was found to be $5.5 \%$ in our patients with OCC and the duration of survival in the OCC patients was found to be shorter than in LC patients. Goetze and Paolucci (26) emphasized the safety of LC as reliable as OC as a surgical method, independent of $\mathrm{T}$ stage in patients with IGC. In their study including 91.260 patients, Pitt et al. (14) reported an OCC rate of $2 \%$ in 91.260 patients who underwent cholecystectomy and an IGC incidence of $0.6 \%$ in patients with OCC. In the present study, we observed

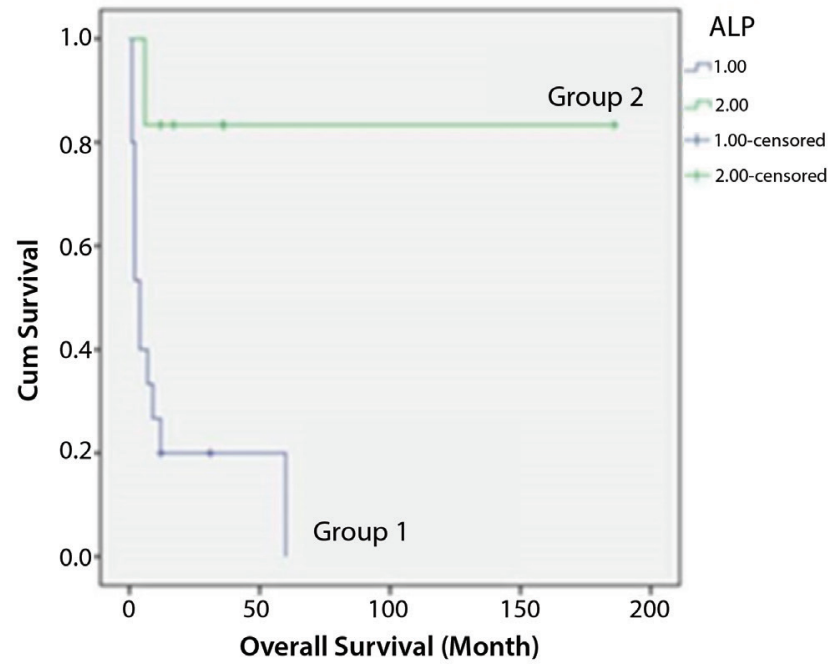

Figure 6. Kaplan-Meier survival curves by the activities of alkaline phosphatase (ALP). (Group 1 high ALP activity, Group 2 normal ALP activity) that within the first 6 months after LC surgery, the survival rate was $63 \%$, whereas it was $30 \%$ in OCC cases.

GP during surgery should be considered as a poor prognostic factor for the probability of recurrence or survival (2). Shimizu et al. (19) concluded that prevention of peritoneal recurrences and favorable prognosis were strongly related with the prevention of intraperitoneal bile spillage during LC. Goetze and Paolucci (26) reported an intraoperative perforation rate of $23 \%$ for LC, $21 \%$ for OC, and 35\% for OCC. However, one study has not found a relationship between survival and an intraperitoneal spillage (16). In our study, the rate of GP was $28.6 \%$. In our surgical series of LC, GP occurred in six patients intraoperatively. We did not find a statistically significant relationship between the GP and survival $(p=0.548)$. However, we found shorter survival in our cases of GP, although it was not statistically significant.

Lymph node metastasis in GC is considered to be one of the most important prognostic factors (2). However, LN evaluation is limited in IGC specimens, because LN dissection is not carried out in standard cholecystectomies. In 12 of our IGC cases, no information on regional LN involvement could be found in the reports of pathological specimens.

Butte et al. (11) reported that re-examination of the initial cholecystectomy specimen showed PI in $42.2 \%$ of 83 patients and observed a higher rate of OCC in patients with residual disease. Additionally, D'Hondt et al. (27) suggested that PI should be considered a significant prognostic factor for survival. We found no effects of PI on survival (Table 2). However, PI was determined in seven of the OCC cases. Although not statistically significant, we have found that Pl-negative patients had longer survival.

Gallbladder anatomy facilitates early hepatic infiltration, since there is no muscularis mucosa or serosal layer in the liver attached to the gallbladder $(10,28)$. Kondo et al. (20) classified the pattern of dissemination of tumor with a focus on surgical strategy in surgical specimens from 112 patients who underwent curative resection for GC. They reported the median survival of 18 months for the whole series, 2 months for the LN dissemination type, and 11 months for the hepatic bed dissemination type (20). Seven of our cases were bed type tumors. Whether on the liver bed or on the peritoneal surface, location of the tumor was not found to be a prognostic factor for survival in the current study. However, survival was found to be some longer in patients with IGC involving the peritoneal surface.

The most common histopathological type of GC is adenocarcinoma (80-97\%). The remaining (3-20\%) histopathological types of GC comprise of squamouscell, adenosquamous-cell carcinoma, or papillary carcinoma. Histopathological types of our IGC consisted 
of adenocarcinoma (85.7\%), neuroendocrine carcinoma, and adenosquamous carcinoma (Table 2).

Chatelain et al. (29) assesses the accuracy of pathology reports in 100 patients who received the diagnosis of IGC and reported that $93 \%$ of reports had a conventional format without any standardization and lacked important information on key histological prognostic factors such as exact tumor site, depth of tumor infiltration within the gallbladder wall, surgical margins, tumor differentiation, vascular invasion and perineural invasion in 55\%, 10\%, $40 \%, 28 \%, 52 \%$, and 51 of cases. Only $30 \%$ of the reports gave information on $\mathrm{T}$ stage with margin status and tumor location. They found that the turnaround time for pathology reports was 1-35 days (mean 7 days). TNM, $R$ status, tumor location and histopathological prognostic factors were mentioned in the pathology reports of our patients. We linked this phenomenon to the fact that our institution was a tertiary hospital.

One of the most important factors for survival in patients with IGC is the depth of tumor invasion (T stage) $(27,30)$. IGC is often detected in T2 and T3 stages $(10,14,18)$. Due to the widespread use of $L C, I G C s$ are detected more frequently in early stages (T1 or T2) nowadays $(6,16,17,31)$. We found that the rate of stages $\mathrm{T} 2$ and $\mathrm{T} 3$ was $33.3 \%$ and $52.4 \%$, respectively. Due to the exclusion of re-operated cases, T3 IGC was more frequently diagnosed than other $T$ stages. Non-resected GC is known to be a rapidly disseminating and fatal disease (27). The median survival for IGC has been reported to be either more favorable or similar when compared to non-incidental GC $(2,7,21,27,32)$. D'Hondt et al. (27) reported a mean survival of 25.8 months in their patients with IGC and 4.4 months in non-incidental GC patients. The median survival in our cases was $7.00 \pm 3.81$ months. The short duration of median survival in our cases clearly indicates the importance of re-operation. For patients with T1a or Tis disease, the standard curative procedure is a simple cholecystectomy with negative SM. $(8,10,15,30-32)$. Liver resection and $L N$ dissection are recommended by the National Comprehensive Cancer Network (NCCN) (33). We had two T1b IGC cases in our LC series. The tumors were located in the fundus and body on the peritoneal surface of the gallbladder. In both patients, there were no LVI or PI. Both patients had a regional $L N$, found to be metastasis-free in the pathology examination. The histopathological type of the tumor was well-differentiated adenocarcinoma and the patients underwent simple LC. ALP activity in these patients was within the normal range. We have not performed reoperation, since the patients did not give consent for further surgery.

Hamdani et al. (5) and Pitt et al. (14) stressed that higher ALP activity was a significant risk factor for IGC. Moreover, they reported that higher GGT and/or ALP activity may occur even in the absence of jaundice (5). The mean ALP activity was $177 \pm 120 \mathrm{IU} / \mathrm{L}$ in our study. We also did not detect jaundice in our patients with higher ALP activity. We found that high ALP activity was strongly associated with poor survival.

\section{Study Limitations}

Small number of patients with T1 and T4 IGC and its retrospective design were the limitations of our study.

\section{Conclusion}

In summary, female gender and advanced age were common in our series.

OCC, high ALP, advanced T stage, LVI and positive of SM are statistically significant poor prognostic factors. Although not statistically significant, development of GP during surgery, poor differentiation histologic grade, $T D \geq 35 \mathrm{~mm}$, location of the tumor in the hepatic bed and, PI shorten survival. Pathology reports should provide information about all of these histopathologic prognostic factors to avoid loss of time associated with re-examination of specimens due to absence of sufficient information in the initial pathology report.

The poor overall survival in our cases obviously demonstrates the importance of re-operation in patients with $\mathrm{T} 2$ or T3 IGC.

\section{Acknowledgements}

We would like to thank Halim Issever* for his support in statistical analysis.

*Halim Işsever, İstanbul University, i̇stanbul Faculty of Medicine, Statistical Department, İstanbul, Turkey.

\section{Authorship Contributions}

Design: S.D., O.A., N.K., I.T. Concept: S.D., O.A., N.K., I.T. Data Collection or Processing: S.D., O.A., N.K. Analysis or Interpretation: S.D., I.T. Literature Search: S.D. Writing: S.D.

Conflict of Interest: The authors declare no competing interest. No grant or other financial support has been received for the drawing up of the present paper.

Financial Disclosure: The authors declared that this study received no financial support.

\section{References}

1. Zhang WJ, Xu GF, Tian ZQ, et al. Surgical approach does not influence the outcome of incidental gallbladder carcinoma. Int J Clin Exp Med 2015;8:869-75.

2. Ahn Y, Park CS, Hwang $S$, et al. Incidental gallbladder cancer after routine cholecystectomy: when should we suspect it preoperatively and what are predictors of patient survival? Ann Surg Treat Res 2016;90:131-8.

3. Glauser PM, Strub D, Kaser SA, et al. Incidence, management, and outcome of incidental gallbladder carcinoma: analysis of 
the database of the Swiss association of laparoscopic and thoracoscopic surgery. Surg Endosc 2010;24:2281-6.

4. Goetze TO, Paolucci V. Adequate extent in radical re-resection of incidental gallbladder carcinoma: analysis of the German Registry. Surg Endosc 2010;24:2156-64.

5. Hamdani NH, Qadri SK, Aggarwalla R, et al. Clinicopathological study of gall bladder carcinoma with special reference to gallstones: our 8-year experience from eastern India. Asian Pac J Cancer Prev 2012;13:5613-7.

6. Siddiqui FG, Memon AA, Abro AH, et al. Routine histopathology of gallbladder after elective cholecystectomy for gallstones: waste of resources or a justified act? BMC Surg 2013;13:26.

7. Duffy A, Capanu M, Abou-Alfa GK, et al. Gallbladder cancer (GBC): 10-year experience at Memorial Sloan-Kettering Cancer Centre (MSKCC). J Surg Oncol 2008;98:485-9.

8. Goetze TO. Gallbladder carcinoma: Prognostic factors and therapeutic options. World J Gastroenterol 2015;21:12211-7.

9. Tantia O, Jain M, Khanna S, et al. Incidental carcinoma gall bladder during laparoscopic cholecystectomy for symptomatic gall stone disease. Surg Endosc 2009;23:2041-6.

10. Yildirim E, Celen O, Gulben K, et al. The surgical management of incidental gallbladder carcinoma. Eur J Surg Oncol 2005;31:45-52.

11. Butte JM, Kingham TP, Gonen $M$, et al. Residual disease predicts outcomes after definitive resection for incidental gallbladder cancer. J Am Coll Surg 2014;219:416-29.

12. Rammohan A, Cherukuri SD, Sathyanesan J, et al. Incidental gall bladder cancers: Are they truly incidental? World J Gastrointest Oncol 2014;6:441-3.

13. Marcial-Rojas RA, Medina R. Unsuspected carcinoma of the gallbladder in acute and chronic cholecystitis. Ann Surg 1961;153:289-98.

14. Pitt SC, Jin LX, Hall BL, et al. Incidental gallbladder cancer at cholecystectomy: when should the surgeon be suspicious? Ann Surg 2014;260:128-33.

15. Martins-Filho ED, Batista TP, Kreimer F, et al. Prevalence of Incidental Gallbladder Cancer in a Tertiary-Care Hospital from Pernambuco, Brazil. Arq Gastroenterol 2015;52:247-9.

16. Kim JH, Kim WH, Kim JH, et al. Unsuspected gallbladder cancer diagnosed after laparoscopic cholecystectomy: focus on acute cholecystitis. World J Surg 2010;34:114-20.

17. Panebianco A, Volpi A, Lozito $C$, et al. Incidental gallbladder carcinoma: our experience. G Chir 2013;34:167-9.

18. Choi KS, Choi SB, Park P, et al. Clinical characteristics of incidental or unsuspected gallbladder cancers diagnosed during or after cholecystectomy: a systematic review and meta-analysis. World J Gastroenterol 2015;21:1315-23.

19. Shimizu T, Arima $Y$, Yokomuro $S$, et al. Incidental gallbladder cancer diagnosed during and after laparoscopic cholecystectomy. J Nippon Med Sch 2006;73:136-40.
20. Kondo S, Nimura Y, Kamiya J, et al. Mode of tumor spread and surgical strategy in gallbladder carcinoma. Langenbecks Arch Surg 2002;387:222-8.

21. Mazer LM, Losada HF, Chaudhry RM, et al. Tumor characteristics and survival analysis of incidental versus suspected gallbladder carcinoma. J Gastrointest Surg 2012;16:1311-7.

22. Compton CC, Byrd DR, Garcia-Aguilar J, et al. Gallbladder. In: Compton CC, Byrd DR, Garcia-Aguilar J, Kurtzman SH, Olawaiye A, Washington MK, editors. AJCC Cancer Staging Atlas: A Companion to the Seventh Editions of the AJCC Cancer Staging Manual and Handbook. Second Edition ed. New York: Springer-Verlag; 2012. p. 259-68.

23. Litynski GS. Profiles in laparoscopy: Mouret, Dubois, and Perissat: the laparoscopic breakthrough in Europe (19871988). JSLS 1999;3:163-7.

24. Donmez T, Uzman S, Yildirim D, et al. Is there any effect of pneumoperitoneum pressure on coagulation and fibrinolysis during laparoscopic cholecystectomy? PeerJ 2016;4:e2375.

25. Zhang WJ, Xu GF, Zou XP, et al. Incidental gallbladder carcinoma diagnosed during or after laparoscopic cholecystectomy. World J Surg 2009;33:2651-6.

26. Goetze TO, Paolucci V. Prognosis of incidental gallbladder carcinoma is not influenced by the primary access technique: analysis of 837 incidental gallbladder carcinomas in the German Registry. Surg Endosc 2013;27:2821-8.

27. D'Hondt M, Lapointe R, Benamira Z, et al. Carcinoma of the gallbladder: patterns of presentation, prognostic factors and survival rate. An 11-year single centre experience. Eur J Surg Oncol 2013;39:548-53.

28. Fujita T. Surgical strategy for incidental gallbladder cancer. J Am Coll Surg 2015;220:254-6.

29. Chatelain D, Fuks D, Farges O, et al. Pathology report assessment of incidental gallbladder carcinoma diagnosed from cholecystectomy specimens: results of a French multicentre survey. Dig Liver Dis 2013;45:1056-60.

30. Yi X, Long $X$, Zai $H$, et al. Unsuspected gallbladder carcinoma discovered during or after cholecystectomy: focus on appropriate radical re-resection according to the T-stage. Clin Transl Oncol 2013;15:652-8.

31. Cavallaro A, Piccolo G, Panebianco V, et al. Incidental gallbladder cancer during laparoscopic cholecystectomy: managing an unexpected finding. World J Gastroenterol 2012;18:4019-27.

32. Ferrarese AG, Solej M, Enrico S, et al. Diagnosis of incidental gallbladder cancer after laparoscopic cholecystectomy: our experience. BMC Surg 2013;13 Suppl 2:S20.

33. Benson AB 3rd, Abrams TA, Ben-Josef E, et al. NCCN clinical practice guidelines in oncology: hepatobiliary cancers. J Natl Compr Canc Netw 2009;7:350-91. 